\title{
Analysis of thermal-electrical performance of PVT collector with reflectors
}

\author{
Hanan Boulaich, Assia Benkaddour, Ouafae Hamdoun, Elhassan Aroudam \\ Physics department, Modeling and Simulation of Mechanical Systems Team Faculty of Sciences, Abdelmalek Essaadi \\ University, Morocco
}

\begin{abstract}
Article Info
Article history:

Received Dec 19, 2020

Revised Mar 31, 2021

Accepted Apr 20, 2021

\section{Keywords:}

Optimal position

PVT collector

Reflectors

ABSTRACT

This work concerns numerical studies of PVT air collector operating in dynamic mode. We presented the temperature of the solar cells and of the air at the outlet of the PVT collector with and without reflectors. The obtained simulation results have been validated by comparating with the experimental results available in literature, where good agreement was been noted. In addition, we determine the optimal position of the reflectors by numerical calculation, in order to obtain the maximal concentration of the solar radiation intensity on PV/T collector. The thermal and electrical efficiency of $\mathrm{PV} / \mathrm{T}$ collector without reflectors and with reflectors in optimal position have been calculated for composite climate at Tetouan $\left(-5^{\circ} \mathrm{N}, 35.5^{\circ} \mathrm{E}\right)$. So, the effect of adding solar reflectors on the electrical and thermal performance is showing.
\end{abstract}

Solar energy
This is an open access article under the CC BY-SA license.

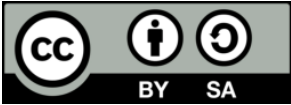

\section{Corresponding Author:}

Hanan Boulaich

Physics department

Modeling and Simulation of Mechanical Systems Team Faculty of Sciences

Abdelmalek Essaadi University, Tetouan 93000, Morocco

Email: hanan.boulaich14@gmail.com

\section{INTRODUCTION}

Solar energy, a type of renewable energy, has a positive effect on the environment; contributes to minimizing $\mathrm{CO}_{2}$ emissions into the atmosphere. Currently, it is operated by a variety of applications, including space heating, water heating, drying of agri-food products, solar refrigeration, and electrical energy produced by systems photovoltaic.

The integrated of the solar thermal and solar photovoltaic systems have evolved considerably, the two technologies provide the opportunity to increase use of solar energy and enhance efficiency, these systems PV/T collectors deliver both electrical energy and thermal at the same time, also provide more useful energy of collector than separate photovoltaic and thermal systems.

Some of the earliest research papers on PV/T systems date back to the 1970s, Kern Jr, E.C., and Russel, M.C [1] and Florschuetz L.W., [2] have recently received renewed interest and expected to become increasingly interesting in the future, because the combination of the two technologies offers the opportunity to increase efficiency and expand the use of solar energy.

A bibliographic synthesis of PVT solar collectors was carried out, which enabled us to note that research on solar collectors have been the focus on improving performance and innovation, including the work of A. Tiwari, M.S. Sodha, A. Chandra, and J.C. Joshi [3] which investigated the performance of the photovoltaic (PV) module integrated with air duct. They validated the theoretical and experimental result for composite climate of India and they concluded that an overall thermal efficiency of PVT system is significantly increased due to utilization of the thermal energy from PV module. A.S. Joshi, A. Tiwari, G.N. 
Tiwari, I. Dincer, and B.V. Reddy [4] have studied the performance of unglazed hybrid photovoltaic thermal (PV/T) glass-to-glass system for composite climate of New Delhi and the comparison with glass-to-tedlar (PV/T) system.

S. Kumar, and A. Tiwari [5] Investigated the concept of a novel self-contained integrated photovoltaic/thermal (PV/T) hybrid solar still, which was developed and verified for a composite climate at I.I.T. New Delhi. This PV system has been employed to generate electricity to run the pump (60W and $18 \mathrm{~V})$; the innovative structure of the hybrid-active solar still allows working in any remote location due to its autonomous nature.

Sandnes, B., and Rekstad, J. also [6] tested the PV/T unit experimentally to determine thermal and photovoltaic performance, and used a polymer solar heat collector that has been combined with monocrystalline silicon photovoltaic cells in a production unit of hybrid energy that simultaneously produced heat and electricity at low temperatures. As well, Y. Tripanagnostopouls [7] studied hybrid PV/TH solar collectors with either air or water as a heat transfer fluid, which can be integrated into buildings. The objective of their work was to reduce the operating temperature of the PV modules, to increase the production of preheated air and to reduce thermal losses through the insulation.

In addition to that, Ahmad Fudholi, et. al. [8] performed analytical studies on energy and exergy efficiency of the PVT air collector with monofacial and bifacial solar cells, the latter is made up of two active surfaces that can capture more of the solar radiation with their front and back surfaces, therefore more performance compared to conventional monofacial PV. P. Dupeyrat, C. Menezo, and S. Fortuinc [9] compared numerically and experimentally a photovoltaic-thermal system with a conventional solar system, they indicated that (PVT) is the more advantageous system, with respect to energy saving and primary energy consumption. N.S.B. Rukman, and A. Fudholi [10] Presented the energy and energy efficiency of waterbased PVT systems and summarized previous studies on the development of this system, also explained water PVT system models.

R. Kumar, and M. Arosen [11] Have critically review photovoltaic-thermal solar collectors for air heating and recent advances, their discussions Included of the status, development and applications of various $\mathrm{PV}$ and solar thermal technologies, and major developments in PV/T collectors and PV/T air heater systems. Their objective is to increase understanding of solar PV/T collectors and heaters and help increase their adoption. Y. Yu, E. Long, Xi Chen, and Hongxing Yang [12] have installed Unglazed Photovoltaic Thermal Collector in Chengdu, Sichuan Basin were input the measured ambient data and operation data to two TRNSYS models and were compared the results, by calibrating the models with experimental data, they reduced the deviation between the simulated and the measured values. In addition, the excellent performance of the roll-bond PVT absorber was also validated by the steady-state test results.

As for studies related to flat reflectors, LjT. Kostic, TM. Pavlovic, and ZT. Pavlovic [13] reported on the results of the influence of reflectance of flat-plate solar reflectors, made of aluminium sheet and aluminium foil, on the energy efficiency of PV/T collectors. They presented both experimental and analytical results of the optimal position of aluminum sheet made flat plate solar reflectors during the daytime over the whole year. Similarly, H. P. Garg, R.K. Agarwal, and Ashok Kumar Bhargava [14] studied a PVT-air hybrid system that included a planar booster to increase the intensity of sunlight on the photovoltaic module. They calculated the minimum solar cell area required to operate the pump at a specified rate without and with the boosters.

In this paper, the principal objective is to study the influence of the two planar reflectors on the thermal and electrical performance of a PVT hybrid collector located in southern Morocco. We carry out numerical simulations to determine the optimal inclination angles of the reflectors, and calculate the temperature of the air and the cells without and with reflectors at this site.

\section{HYBRID PVT AIR COLLECTOR}

\subsection{Description of the studied system}

Photovoltaic thermal (PV/T) collectors are devices that simultaneously convert solar radiation into electricity and heat. the simplified diagram of the photovoltaic thermal hybrid collector PV/T collector shown in Figure 1, It consists of a glass cover, monocristalln's photovoltaic module of $1.29 \mathrm{~m}$ length and $0.33 \mathrm{~m}$ width, aluminium absorber placed at the lower part of the module, this absorber is enclosure containing the coolant and insulation to reduce wool heat loss.

The system shown in Figure 2 consists of three different components: the PVT collector, the upper reflector and the lower reflector. The collector is tilted at $35^{\circ}$ and faces south. Both reflectors are tilted to the horizontal plane by $\alpha 1$ and to the vertical plane by $\alpha 2$. 


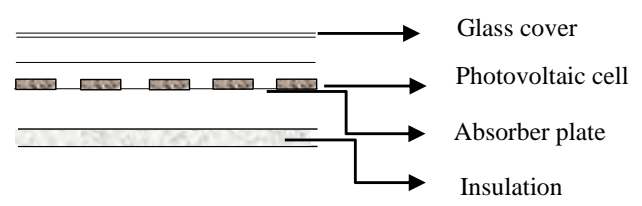

Figure 1. Schematic of PV/T model

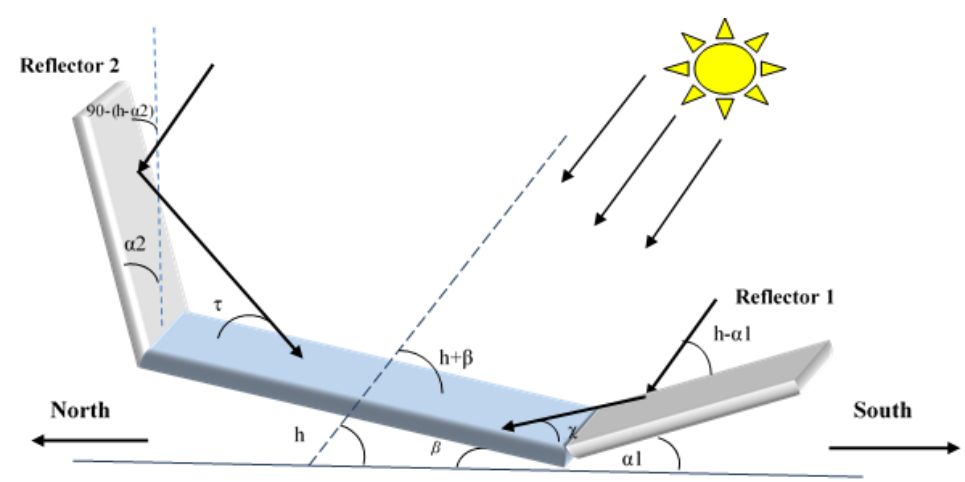

Figure 2. Photovoltaic thermal collector with two reflectors

\subsection{Global thermal expressions for the PV/T solar collector}

The heat balances for each node, in a section slice, are written according to the general shape:

$$
\frac{c_{i}}{\Delta s} \frac{d T_{i}}{d t}=P_{i}+\sum_{i}(h c i+h r i j+h i j)\left(T_{j}-T_{i}\right)
$$

The energy balance for the different parts of the PVT solar collector according to [15].

For the glass cover is:

$$
\frac{\mathrm{M}_{\mathrm{g}} \mathrm{C}_{\mathrm{g}}}{\Delta \mathrm{s} \Delta \mathrm{t}}\left(\mathrm{T}_{\mathrm{g}}-\mathrm{T}_{\mathrm{g}}^{\circ}\right)=\mathrm{P}_{\mathrm{g}}+\mathrm{h}_{\mathrm{w}}\left(\mathrm{T}_{\mathrm{a}}-\mathrm{T}_{\mathrm{g}}\right)+\mathrm{h}_{\mathrm{rg}-\mathrm{sk}}\left(\mathrm{T}_{\mathrm{sk}}-\mathrm{T}_{\mathrm{g}}\right)+\mathrm{h}_{\mathrm{rg}-\text { cell }}\left(\mathrm{T}_{\text {cell }}-\mathrm{T}_{\mathrm{g}}\right)+\mathrm{h}_{\mathrm{g}-\text { cell }}\left(\mathrm{T}_{\text {cell }}-\mathrm{T}_{\mathrm{g}}\right)
$$

for the photovoltaic cells (PV) is:

$$
\frac{\mathrm{M}_{\text {cell }} \mathrm{C}_{\text {pcell }}}{\Delta \mathrm{s} \Delta \mathrm{t}}\left(\mathrm{T}_{\text {cell }}-\mathrm{T}_{\text {cell }}^{\circ}\right)=\mathrm{P}_{\text {cell }}+\mathrm{h}_{\mathrm{g}-\text { cell }}\left(\mathrm{T}_{\mathrm{g}}-\mathrm{T}_{\text {cell }}\right)+\mathrm{h}_{\mathrm{rg}-\text { cell }}\left(\mathrm{T}_{\mathrm{g}}-\mathrm{T}_{\text {cell }}\right)+\mathrm{h}_{\text {ccell-p }}\left(\mathrm{T}_{\mathrm{p}}-\mathrm{T}_{\text {cell }}\right)-\mathrm{Q}_{\text {elec }}
$$

where:

$$
\mathrm{Q}_{\text {elec }}=\eta_{\text {elec }} * \mathrm{P}_{\text {cell }} * \beta_{\text {cell }} * \tau_{\mathrm{g}}
$$

for the absorber plate is:

$$
\mathrm{a} \frac{\mathrm{M}_{\mathrm{p}} \mathrm{C}_{\mathrm{pp}}}{\Delta \mathrm{s} \Delta \mathrm{t}}\left(\mathrm{T}_{\mathrm{p}}-\mathrm{T}_{\mathrm{p}}^{\circ}\right)=\mathrm{P}_{\mathrm{p}}+\mathrm{h}_{\text {ccell-p }}\left(\mathrm{T}_{\text {cell }}-\mathrm{T}_{\mathrm{p}}\right)+\mathrm{h}_{\mathrm{p}-\mathrm{f}}\left(\mathrm{T}_{\mathrm{f}}-\mathrm{T}_{\mathrm{p}}\right)+\mathrm{h}_{\mathrm{rbp}-\mathrm{p}}\left(\mathrm{T}_{\mathrm{pb}}-\mathrm{T}_{\mathrm{p}}\right)
$$

for the fluid is:

$$
\frac{\mathrm{m}_{\mathrm{f}} \mathrm{C}_{\mathrm{pf}}}{\Delta \mathrm{s} \Delta \mathrm{t}}\left(\mathrm{T}_{\mathrm{f}}-\mathrm{T}_{\mathrm{f}}^{\circ}\right)=\mathrm{h}_{\mathrm{p}-\mathrm{f}}\left(\mathrm{T}_{\mathrm{p}}-\mathrm{T}_{\mathrm{f}}\right)+\mathrm{h}_{\mathrm{pb}-\mathrm{f}}\left(\mathrm{T}_{\mathrm{pb}}-\mathrm{T}_{\mathrm{f}}\right) \text { with: } \mathrm{T}_{\mathrm{f}}=\frac{\mathrm{T}_{\mathrm{fI}}+\mathrm{T}_{\mathrm{fO}}}{2}
$$


for the back plate is:

$$
\frac{\mathrm{M}_{\mathrm{pb}} \mathrm{C}_{\mathrm{ppb}}}{\Delta \mathrm{s} \Delta \mathrm{t}}\left(\mathrm{T}_{\mathrm{pb}}-\mathrm{T}_{\mathrm{pb}}^{\circ}\right)=\mathrm{P}_{\mathrm{pb}}+\mathrm{h}_{\mathrm{pb}-\mathrm{f}}\left(\mathrm{T}_{\mathrm{f}}-\mathrm{T}_{\mathrm{pb}}\right)+\mathrm{h}_{\mathrm{rp}-\mathrm{pb}}\left(\mathrm{T}_{\mathrm{p}}-\mathrm{T}_{\mathrm{pb}}\right)+\mathrm{h}_{\mathrm{cpb}-\mathrm{in}}\left(\mathrm{T}_{\mathrm{in}}-\mathrm{T}_{\mathrm{pb}}\right)+\mathrm{h}_{\mathrm{rpb}-\mathrm{in}}\left(\mathrm{T}_{\mathrm{in}}-\mathrm{T}_{\mathrm{pb}}\right)
$$

for the insulation is:

$$
\frac{\mathrm{M}_{\mathrm{in}} \mathrm{C}_{\mathrm{in}}}{\Delta \mathrm{s} \Delta \mathrm{t}}\left(\mathrm{T}_{\mathrm{in}}-\mathrm{T}_{\mathrm{in}}^{\circ}\right)=\mathrm{h}_{\mathrm{rpb}-\text { in }}\left(\mathrm{T}_{\mathrm{pb}}-\mathrm{T}_{\mathrm{in}}\right)+\mathrm{h}_{\mathrm{cpb}-\mathrm{in}}\left(\mathrm{T}_{\mathrm{pb}}-\mathrm{T}_{\mathrm{in}}\right)+\mathrm{h}_{\mathrm{in}-\mathrm{s}}\left(\mathrm{T}_{\mathrm{a}}-\mathrm{T}_{\mathrm{in}}\right)+\mathrm{h}_{\mathrm{rin}-\mathrm{s}}\left(\mathrm{T}_{\mathrm{a}}-\mathrm{T}_{\mathrm{in}}\right)
$$

\subsubsection{Convection heat transfer coefficient}

The convection exchanges that occur in the system under study are:

a. The convection between the glass and the atmosphere, calculated by Mc Adams [16]:

$$
\mathrm{h}_{\mathrm{w}}=5.67+3.86 \mathrm{~V}_{\mathrm{w}}
$$

b. The natural convection of air between the glass and the PV model

$$
\mathrm{h}_{\mathrm{g}-\text { cell }}=\frac{\lambda_{\mathrm{a}} \mathrm{Nu}}{\mathrm{e}_{\mathrm{g}-\text { cell }}}
$$

c. The convection between the fluid and the absorber plate

$$
h_{p-f}=h_{p b-f}=\operatorname{Nuf} \frac{\lambda_{f}}{D_{h}}
$$

Nuf Is the Nusselt number is calculated according to the flow regime; however, the Nusselt groupings corresponding to these regimes are expressed by the equations in [17]. We took the condution and the coefficient of radiation heat transfer from [18], [19].

To solve the equations of this model, the iterative numerical method used is based on the method of Gauss seidel [20]. Indeed, a program was written in Fortran 90 in order to find the values of the temperatures $\mathrm{Tg}$, Tcell, Tp, Tins and Tf of the air collector, as well as the value of the thermal efficiency.

\subsubsection{Thermal efficiency}

The thermal efficiency of the PV/T collector can be expressed as a ratio of the amount of heat extracted by the fluid used, denoted $\mathrm{Qu}(\mathrm{W} / \mathrm{m} 2)$, to the amount of solar radiation incident on the glazing. The thermal efficiency is determined from [21]:

$$
\eta_{\text {th }}=\frac{\mathrm{mC}_{\mathrm{p}}\left(\mathrm{T}_{\mathrm{f}}-\mathrm{T}_{\mathrm{a}}\right)}{\mathrm{A}_{\mathrm{a}} \mathrm{G}_{\text {tot }}}
$$

\subsection{Electrical efficiency}

The electrical efficiency $\eta_{p v}$ of the crystalline silicon (c-Si) solar cells/modules presented by [22]:

$$
\eta_{\mathrm{pv}}=\eta_{\text {ref }}\left[1+\beta\left(\mathrm{T}_{\text {cell }}-298\right)\right]
$$

Where $\eta_{\text {ref }}$ and $\beta$ respectively represent the coefficient of photovoltaic conversion efficiency and the coefficient of photovoltaic conversion efficiency at reference temperature (298 K).

\subsection{The reflectors equations}

The theoretical equations that allow us to carry out the algorithm to calculate the global radiation received by inclined PVT collector, are the formula of the solar altitude and azimuth angles, also we use the program FORTRAN as a tool of test and simulation to determine the trajectory of the sun immediately. 
The instantaneous solar altitude angle $\mathrm{h}$ is given by [23]:

$\sinh =\sin \varphi \sin \delta+\cos \varphi \cos \delta \cos \omega$

where:

$\varphi$ Is the latitude of the location

$\delta$ Is the declination angle given by.

$\delta=23.54^{\circ} \sin \left[0.980^{\circ}(\mathrm{N}+287)\right]$

$\omega$ Is the hour angle, which defined as:

$\omega=15^{\circ}(\mathrm{TSV}-12)$

The extraterrestrial beam radiation reaches the ground is:

$\mathrm{i}=\mathrm{i}_{\mathrm{oh}} * 0.7^{\mathrm{AM}} \mathrm{M}^{0.678}$

With

$$
\mathrm{AM}=\left[\cos \theta_{\mathrm{z}}+0.50572\left(96.07995+\theta_{\mathrm{z}}\right)^{-1.6364}\right]^{-1}
$$

The approximate intensity of solar radiation on the ground at a given location can be measured by calculating the extraterrestrial intensity $i_{0}$ on a surface that is perpendicular to the sun on a given day of the year, according to N. Kumar, G.Vishwanath, A.Gupta [24]:

$$
\begin{aligned}
& \mathrm{i}_{\mathrm{oh}}=\mathrm{i}_{\mathrm{O}} * \cos \theta_{\mathrm{z}} \\
& \mathrm{i}_{0}=\left(\mathrm{i}_{\mathrm{sc}} *\left[1+0.0334 * \cos \left(\frac{2 \pi(\mathrm{N}-1)}{365.25}\right)\right]\right)
\end{aligned}
$$

Where $i_{\mathrm{sc}}=1367 \mathrm{~W} / \mathrm{m}^{2}$ is the solar constant, and $\theta_{z}$ is the zenith angle of the sun, correlated to the altitude angle as (21).

$$
\theta_{\mathrm{z}}=90-\mathrm{h}
$$

In order to calculate the solar radiation $G$ on the inclined PVT collector with $\beta$, we have used the following expressions [25]:

$$
\mathrm{G}=\mathrm{Gdir}+\mathrm{Gdif}+\mathrm{Ggr}+\mathrm{Gr} 1+\mathrm{Gr} 2
$$

Where:

$$
\begin{aligned}
& \mathrm{Gdir}=\mathrm{Gin} * \sin (\beta+\mathrm{h}) \\
& \mathrm{Gdif}_{\mathrm{d}}=\mathrm{Gd}_{\mathrm{d}} * \frac{1+\cos \beta}{2} \\
& \mathrm{Ggr}=\rho \mathrm{g} * \mathrm{Gh} * \frac{1-\cos \beta}{2} \\
& \mathrm{Gr} 1=\rho \mathrm{al}{ }^{*} \mathrm{Gin}^{*} \sin \chi^{*} \sin (\mathrm{h}-\alpha 1) \Rightarrow \chi=\beta+2 * \alpha 1-\mathrm{h} \\
& \mathrm{Gr} 2=\rho \mathrm{al}{ }^{*} \mathrm{Gin}^{*} \sin \tau^{*} \sin (\mathrm{h}+\alpha 2) \Rightarrow \tau=\mathrm{h}+2 * \alpha 2-\beta
\end{aligned}
$$




\section{RESULTS AND DISCUSSION}

The total radiation falling on PVT collector tilted at a fixed orientation with and without reflectors, and the ambient air temperature are plotted in Fig.3. The collector is oriented $35.5^{\circ}$ to the south, while the angle of the reflectors can changed $\alpha 1$ the angle of the lower reflector is changed from $7^{\circ}$ to $82^{\circ}$, while the angle of upper reflector is changed from $10^{\circ}$ to $35^{\circ}$. So, we optimize the angles of the reflectors to reach a higher intensity of solar radiation falling on the PVT surface, from the curves of Figure 4, we conclude that the optimal value of $\alpha 1$ is $37^{\circ}$ and $\alpha 2$ is $10^{\circ}$ during May 2 at 12:00 noon.

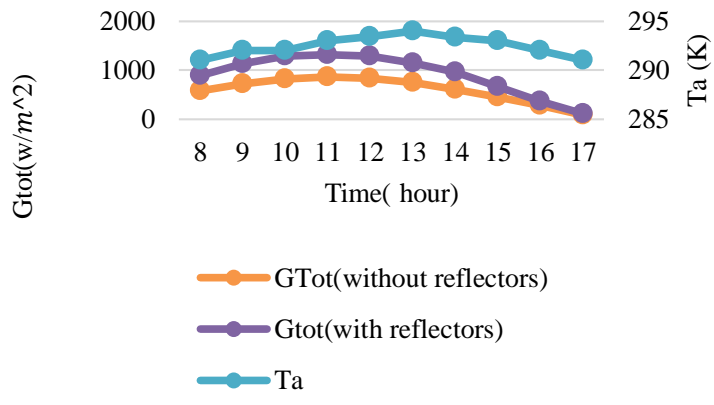

Figure 3. Hourly solar radiation on PV/T collector with and without reflectors

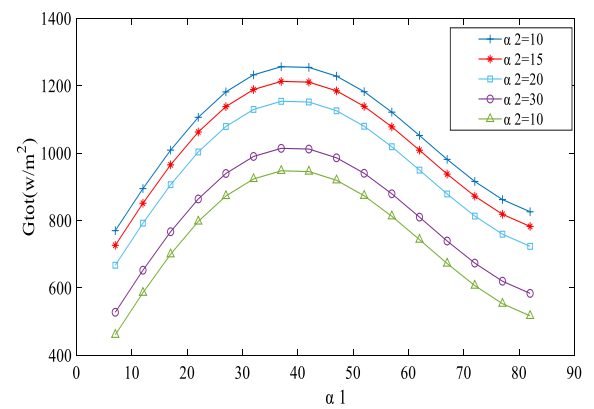

Figure 4. A change of total solar radiation on PV/T collector depending on reflectors position

In Figure 5, we have presented the air outlet temperature given by Touafik [26] and our model without reflectors in June 15. We observed that the result of our simulation is in good agreement with the experimental results.

In this comparaison, we kept the same properties of the system used in the experiment, except the absorber plate equipped with rectangular fins. Although not used the fins. The air outlet temperature of our model is almost equal to the temperature of [26], so we have found that our model is efficient can be used to improve the performance of the PV/T collector.

Figure 6 show the air temperature at the outlet of the PVT collector for 4 may without and with reflectors in optimal position, we notice that the latter is higher than the outlet temperature of the air in the collector without reflectors. Because these temperature values are related to the intensity of solar radiation.

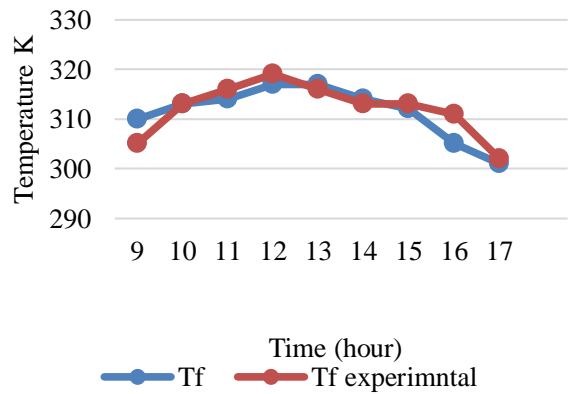

Figure 5. Validation of the mathematical model of Hourly variations of the outlet air Temperatures of the $\mathrm{PV} / \mathrm{T}$ collector

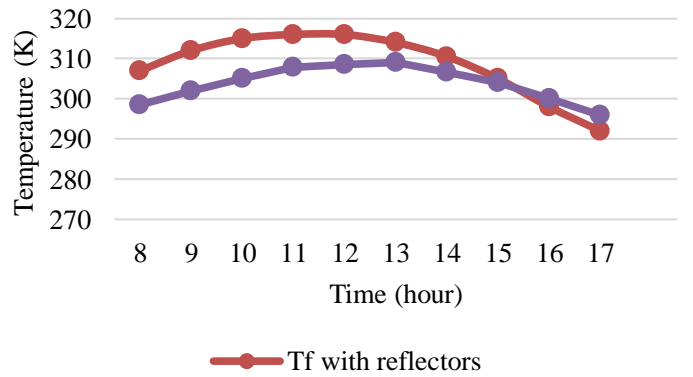

Figure 6. Effect of reflectors on the temperature Outlet of air of PVT collector

Figure 7 illustrates the comparaison of the temperature of the solar cell without reflectors and with reflectors of our numerical program with the temperature without reflectors available in the experimental study of [27] (4 May 2016). According to the graphs, there is a concordance between their experimental results and our theoretical results. The temperature of the solar cell varies from a minimum value of $320 \mathrm{~K}$ at $8 \mathrm{~h} 00$ to a maximum of $340 \mathrm{~K}$ at $13 \mathrm{~h} 00$, with a root mean square between the experimental values and those 
of our numerical simulation $2 \%$. These differences may be due to hypotheses and uncertainties in the correlations used in the mathematical analysis. Therefore, we observe that the temperature of PV cells with reflectors is high due to the increased radiation reflected from the reflectors.

From the figure 8, we can see the thermal efficiency of PVT collector without Reflectors is near than thermal efficiency of PVT collector with reflectors. This result indicates that the reflectors does not have a great influence on the performance for this site, because we have different factors that influence the thermal performance of the collector such as climatic conditions, incident energy, and outside temperature. The geometry of the collector. However, to have a better efficiency, we must maintain a wide temperature difference between the inlet and outlet of the heat transfer fluid in addition to raise the thermal conductivity of the materials.

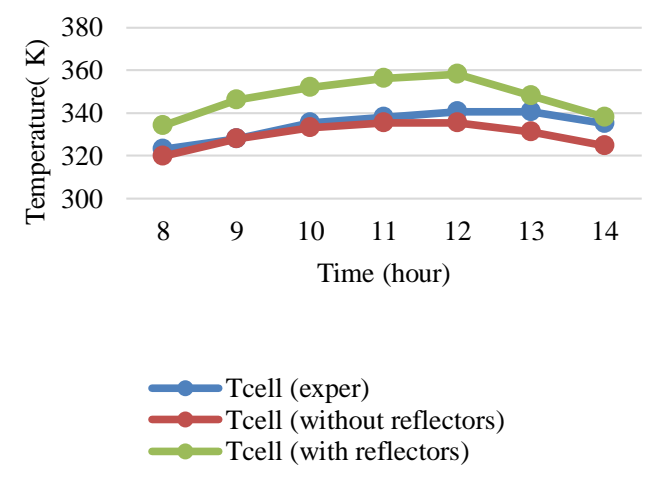

Figure 7. Effect of reflectors on the temperature Outlet of air of PVT collector

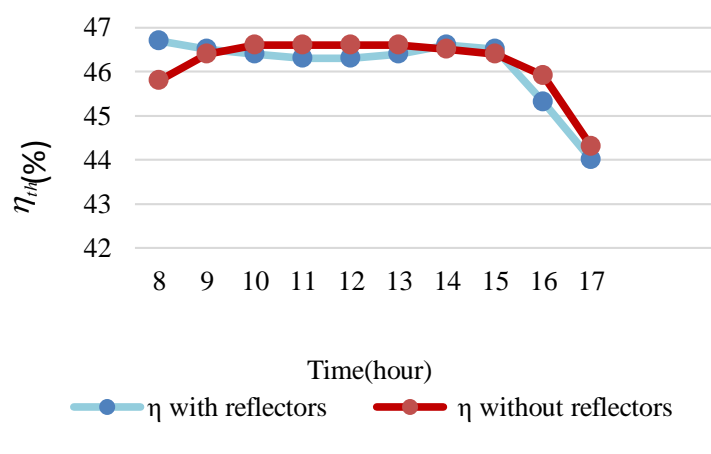

Figure 8. The effect of reflectors on the thermal efficiency of PVT collector

The electrical efficiency of the PV/T collector with and without reflectors during the day (4 may) for the optimal position of the reflectors is presented in Figure 9. In this figure, we can see that the electrical efficiency of the collector with reflector is lower than the efficiency without reflectors, due to the increase in absorbed solar radiation; this radiation increases the temperature of the cells.

Therefore, we conclude that the absorbed solar radiation increases the temperature of the cells and reduces its efficiency. The electrical yield of the collector with reflector is lower than the yield without reflector, which causes an increase in absorbed solar radiation.

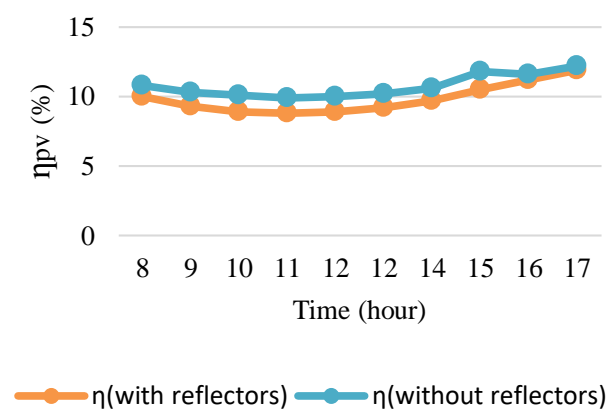

Figure 9. The effect of reflectors on the electrical efficiency of PVT collector

\section{CONCLUSION}

In this paper, a mathematical model for a solar photovoltaic thermal (PV/T) has been developed. The validity of this model was testing by comparing simulation results to experimental ones found in the literature where we obtained a good agreement.

A change of the optimal angle of the reflectors during the day was analytically determined when the panel is fixed at $\beta=35^{\circ}$. Then, we calculated the temperature of the cell and the fluid outlet with and without reflectors. Based on the results of the simulation, we found that these temperatures related to the variation of 
solar radiation during the selected day. On the other hand, the numerical results show that the addition of the two reflectors at this site did not greatly improve the thermal and the electrical performances of this collector type.

As a perspective of this work, we aim to improve the performance of hybrid collectors such as using nanofluids as cooling fluid because they have high thermophysical properties.

APPENDIX

\begin{tabular}{|c|c|c|}
\hline Notation & Description & Unit \\
\hline$A_{a}$ & Collector surface area & $m^{2}$ \\
\hline$C_{p}$ & Specific heat & $\mathrm{J} / \mathrm{kg} \mathrm{K}$ \\
\hline$m$ & Mass air flow rate & $\mathrm{kg} / \mathrm{s}$ \\
\hline M & Mass & $\mathrm{kg}$ \\
\hline$T$ & Temperature & $\mathrm{K}$ \\
\hline$T^{\circ}$ & Temperature of the previous slice & $\mathrm{K}$ \\
\hline$P$ & Power absorbed by glass & $\mathrm{w}$ \\
\hline $\mathrm{Nu}$ & Nusselt number & \\
\hline$D_{h}$ & Equivalent hydraulic diameter of the useful duct & $\mathrm{m}$ \\
\hline$h$ & Convection heat transfer coefficient & $\mathrm{w} / \mathrm{m}^{2} \cdot \mathrm{K}$ \\
\hline$\Delta s$ & Length of a slice along the tube axis & $\mathrm{m}$ \\
\hline$\Delta t$ & Time of a slice along the tube axis & $\mathrm{s}$ \\
\hline $\bar{V}_{w}$ & Wind velocity & $\mathrm{m} / \mathrm{s}$ \\
\hline$Q_{\text {elec }}$ & The electrical power produced by the solar cell & $\mathrm{w} / m^{2}$ \\
\hline TSV & Local solar time in hours & \\
\hline $\mathrm{N}$ & The day number of the day in the year & \\
\hline$i_{o}$ & Extraterrestrial intensity on a surface held perpendicular to the sun & \\
\hline $\mathrm{i}$ & The solar radiation intensity on a horizontal surface & \\
\hline$i_{\text {oh }}$ & The extraterrestrial radiation intensity on a horizontal surface & \\
\hline Gdir & The direct radiation on the collector & \\
\hline Gdif & The sky-diffuse radiation & \\
\hline Ggr & The reflected radiation from the ground & \\
\hline Gr1 & $\begin{array}{l}\text { The reflected radiation from bottom reflector which reached the collector } \\
\text { Surface with titled angle } \alpha 1 \text {. }\end{array}$ & \\
\hline Gr2 & $\begin{array}{l}\text { The reflected radiation from the upper reflector which reached the collector } \\
\text { Surface with titled angle } \alpha 2 \text {. }\end{array}$ & \\
\hline Gin & The global solar incident radiation & \\
\hline$G d$ & The global solar diffuse radiation & \\
\hline$G h$ & The global solar radiation on horizontal surface & \\
\hline
\end{tabular}

\begin{tabular}{cl}
\hline Greek letters & \\
\hline$\lambda$ & Thermal conductivity (W/m K) \\
$\tau_{g}$ & Transmissivity of the glass \\
$\beta$ & Fill factor is the ratio of the area covered by the PV cells to the total area of the PV module \\
$\Omega$ & The hour angle \\
$\varphi$ & The latitude of the location \\
$\delta$ & Declination angle \\
\hline Subscript & \\
\hline $\mathrm{a}$ & Ambient air \\
$\mathrm{sk}$ & Sky \\
$\mathrm{gr}$ & Ground \\
$\mathrm{w}$ & Wind \\
$\mathrm{I}$ & Inlet \\
$\mathrm{g}$ & Cover \\
$\mathrm{cell}$ & Photovoltaic cells \\
$\mathrm{p}$ & Absorber plate \\
$\mathrm{f}$ & Fluid (air Stream) \\
$\mathrm{pb}$ & back plate of absorber \\
in & Initial or inlet \\
$\mathrm{O}$ & Outlet
\end{tabular}

\section{REFERENCES}

[1] Kern Jr, E.C., and Russel, M.C., "Combined photovoltaic and thermal hybrid collector system," Proceedings of the 13th IEEE Photovoltaic Specialists, 1978, pp. 1153-1157.

[2] Florschuetz L.W., "Extension of the Hottel-Whillier model to the analysis of combined photovoltaic/thermal flat plate collectors," Solar Energy, vol. 72, no. 4, pp. 361-366, 1979, doi: 10.1016/0038-092X(79)90190-7 
[3] A. Tiwari, M.S. Sodha, A. Chandra, and J.C. Joshi, "Performance evaluation of photovoltaic thermal solar air collector for composite climate of India," Solar Energy Materials and Cells, vol. 90, no. 2, pp. 175-189, 2006, doi: 10.1016/j.solmat.2005.03.002

[4] A.S. Joshi, A. Tiwari, G.N. Tiwari, I. Dincer, and B.V. Reddy, "Performance evaluation of a hybrid photovoltaic thermal (PV/T) (glass-to-glass) system,” International Journal of Thermal Sciences, vol. 48, no. 1, pp. 154-164, 2009, doi: 10.1016/j.ijthermalsci.2008.05.001

[5] S. Kumar, and A. Tiwari, "An experimental study of hybrid photovoltaic thermal (PV/T)-active solar still," International Journal of Energy Research, vol. 32, no. 2, pp. 847-58, 2008, doi: 10.1002/er.1388

[6] Sandnes, B., and Rekstad, J., "A photovoltaic/thermal (PV/T) collector with a polymer absorber plate: experimental study and analytic model, “ Solar Energy, vol. 72, no. 1, pp. 63-73, 2009, doi: 10.1016/S0038-092X(01)00091-3

[7] Y. Tripanagnostopouls, "Aspects and improvements of hybrid photovoltaic thermal solar energy systems," Journal of Solar Energy, vol. 81, no. 9, pp. 1117-1131, 2007, doi: 10.1016/j.solener.2007.04.002

[8] Ahmad Fudholi, Muslizainun Mustapha, Ivan Taslim, Fitrotun Aliyah, Arthur Gani Koto, and Kamaruzzaman Sopian, "Photovoltaic thermal (PVT) air collector with monofacial and bifacial solar cells: a review," International Journal of Power Electronics and Drive System (IJPEDS), vol. 10, no. 4, pp. 2021-2028, 2019, doi: 10.11591/ijpeds.v10.i4.2021-2028

[9] P. Dupeyrat, C. Menezo, and S. Fortuinc, "Study of the thermal and electrical performances of PVT solar hot water system,” Energy Buildings, vol. 68, no. part C, pp. 751-755, 2014, doi: 10.1016/j.enbuild.2012.09.032

[10] N.S.B. Rukman, and A. Fudholi, "Energy and exergy efficiency of water-based photovoltaic thermal (PVT) systems: an overview," International Journal of Power Electronics and Drive System (IJPEDS), vol. 10, no. 2, pp. 987-994, June 2019, doi: 10.11591/ijpeds.v10.i2.pp987-994

[11] R. Kumar, and M. Arosen, "A critical review of photovoltaic-thermal solar collectors for air heating," Applied Energy, vol. 88, no. 11, pp. 3603-3614, 2011, doi: 10.1016/j.apenergy.2011.04.044

[12] Y. Yu, E. Long, Xi Chen, and Hongxing Yang, "Performance study on an unglazed photovoltaic thermal collector running in Sichuan Basin,” Energy Procedia, vol. 158, pp. 1249-1254, 2019, doi: 10.1016/j.egypro.2019.01.414

[13] LjT. Kostic, TM. Pavlovic, and ZT. Pavlovic, "Influence of reflectance from flat aluminum concentrators on energy efficiency of PV/Thermal collector," Applied Energy, vol. 87, no. 2, pp. 410-416, 2010, doi: 10.1016/j.apenergy.2009.05.038

[14] H. P. Garg, R.K. Agarwal, and Ashok Kumar Bhargava, "The effect of plane booster reflectors on the performance of a solar air heater with solar cells suitable for a solar dryer," Energy Convers, vol. 32, no. 6, pp. 543-554, 1991, doi: 10.1016/0196-8904(91)90114-X

[15] Ahmad Fudholi, Muhammad Zohri, Ivan Taslim, Fitrotun Aliyah, and Arthur Gani Koto, "Heat transfer and efficiency of dual channel PVT air collector: a review,"International Journal of Power Electronics and Drive System (IJPEDS), vol. 10, no. 4, pp. 2037-2045, 2019, doi: 10.11591/ijpeds.v10.i4.pp2037-2045

[16] Mc Adams WH, "Heat transmission," McGraw-Hill, New York, 1954.

[17] M. Zohri, et al.," Photovoltaic thermal (PVT) system with and without fins collector: theoretical approach, International Journal of Power Electronics and Drive Systems (IJPEDS), vol. 8, no. 4, pp. 1756-63, 2017, doi: 10.11591/ijpeds.v8.i4.pp1756-1763

[18] A. Hegazy, "Comparative study of the performances of four photovoltaic/thermal solar air collectors," Energy Conversion \& Management, vol.41, pp. 861-881, 2000.

[19] N.S. Nazri, Nurato, and Ahmad Fudholi, "Mathematical modeling of photovoltaic thermal-thermoelectric (PVTTE) air collector," International Journal of Power Electronics and Drive Systems (IJPEDS), vol. 9, no. 2, pp. 795$802,2018$.

[20] N. Boumahrat, and Gourdin, “Méthodes numériques,” OPU, 1980.

[21] W. Gao, W. Lin, T. Liu, and C. Xia, "Analytical and experimental studies on the thermal performance of crosscorrugated and flat plate solar air heaters," Applied Energy, vol. 84, no. 4, pp. 425-441, 2007, doi: 10.1016/j.apenergy.2006.02.005

[22] Ahmad Fudholi, Nur Farhana Mohd Razali, Abrar Ridwan, Rado Yendra, Hartono, Ari Pani Desvina, et al., "Overview of photovoltaic thermal (PVT) water collector," International Journal of Power Electronics and Drive Systems (IJPEDS), vol. 9, no. 4, pp. 1891-1898, December 2018, doi: 10.11591/ijpeds.v9.i4.pp1891-1898

[23] LjT. Kostic, TM. Pavlovic, and Z. T. Pavlović, "Optimal design of orientation of PV/T collector with reflectors," Applied Energy, vol. 87, no. 10, pp. 3023-3029, 2010, doi: 10.1016/j.apenergy.2010.02.015

[24] N. Kumar, G.Vishwanath, A.Gupta, "An exergy based unified test protocol for solar cookers of different geometries, " Renewable Energy, vol. 44, pp. 457-462, 2012.

[25] P. Malik, and S.S. Chandel, "Performance enhancement of multi-crystalline silicon photovoltaic modules using mirror reflectors under Western Himalayan climatic conditions," Renewable Energy, vol. 154, pp. 966-975, July 2020, doi: 10.1016/j.renene.2020.03.048

[26] Khaled Touafek, Abdelkrim Khelifa, Lyes Boutina, Ismail Tabet and Salim Haddad, "Theoretical study and experimental validation of energetic performances photovoltaic/Thermal air collector," International Journal of Photo Energy, vol. 2018, 2018, doi: 10.1155/2018/2794068

[27] M. Belhadj, T. Benouaz, "Modeling of automatic reflectors for PV panel attached to commercial PV/T module," International Journal of Applied Engineering Research, vol. 11, no. 20, pp. 11309-11314, 2016. 


\section{BIOGRAPHIES OF AUTHORS}

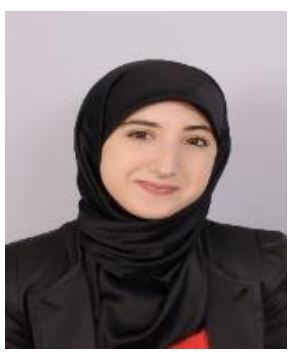

Hanan Boulaich has born Tetouan in 1992 , she received her Bachelor's degree in physics in 2013 and master degree in energy engineering and environment in 2015 from Faculty of Sciences of Tetouan, Abdelmalek Essaadi University, Morocco. She is currently working toward the Ph.D. degree at the Research Team Modeling and Simulation of Mechanical Systems, at the physics department of the same university. Her research interests include modeling and performance of solar systems.

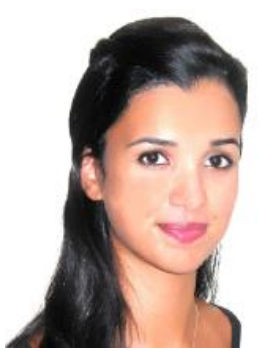

Benkaddour Assia is a PHD student in modeling and simulation of mechanical systems team, physics department at faculty of science Abdelmalek Essaadi university Tetouan, she was born oujda in 1992 and received her master degree in engineering of industrial automated systems from faculty of science of Fez in 2014.

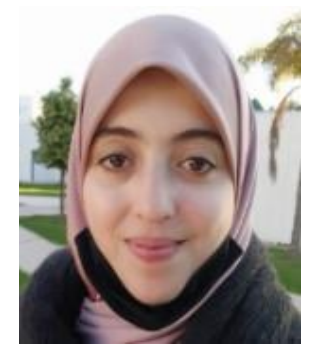

Hamdoun Ouafae obtained her doctor's degree is Mechatronics in 2019 from Abdelmalek Essaadi University of Tetouan, Morocco. She is also a member of the Research Team Modeling and Simulation of Mechanical systems, at the Physics department of the same University.

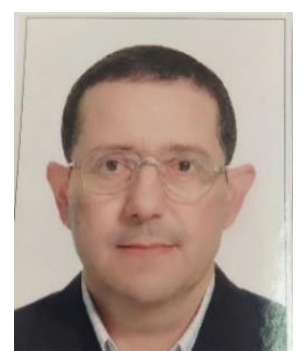

Elhassan Aroudam is a professor at Abdelmalek Essaadi University in Tetouan (Morocco). He obtained his first $\mathrm{PhD}$ in physics from Faculty of Sciences of Tetouan, Abdelmalek Essaadi University, Morocco in 1992 and his state Doctorate in solar energy of the same university in 2002. He has more than 25 years of experience in teaching and research in thermal systems and solar energy. He has presented several research papers at various conferences, which published in international journal. 